\title{
Sistem Pembagian Kerja, Akses dan Kontrol terhadap Sumber Daya Ekonomi dalam Keluarga Peternak Rakyat Sapi Potong di Kabupaten Grobogan
}

\author{
A.I. Sari, S. H. Purnomo dan E. T. Rahayu \\ Program Studi Peternakan Fakultas Pertanian, Universitas Sebelas Maret, Jl Ir. Sutami 36 A, Surakarta
}

\begin{abstract}
ABSTRAK
Penelitian ini bertujuan untuk menganalisis sistem pembagian kerja, akses dan kontrol serta mengetahui faktor-faktor yang menjadi pertimbangan dalam menentukan pembagian kerja, akses dan kontrol terhadap sumber daya ekonomi dalam keluarga peternak rakyat sapi potong, mengetahui besarnya pendapatan yang diterima dari usaha peternakan sapi potong serta peranannya dalam menunjang ekonomi produktif keluarga, serta mengetahui bias gender yang terjadi dalam keluarga peternak rakyat sapi potong. Tahap pengumpulan data penelitian ini telah dilaksanakan dengan lokasi pengambilan data di Kabupaten Grobogan. Metode dasar penelitian yang digunakan adalah metode deskriptif kualitatif, dengan teknik pengambilan sampel secara purposive sampling. Analisis data yang digunakan adalah analisis interaktif (Interactive Model of Analysis). Hasil penelitian menunjukkan bahwa dalam keluarga peternak sapi potong suami lebih banyak berperan dalam pekerjaan yang berkaitan dengan publik (diluar rumah), dan istri hanya bekerja pada sektor domestik yaitu sebagai ibu rumah tangga (62\%), sehingga tidak berpenghasilan (42\%). Pada sistem pembagian kerja untuk aktivitas yang berkaitan dengan produksi mayoritas (95\%) dilakukan oleh suami, dan untuk aktivitas produksi lebih banyak dilakukan oleh istri (91\%). Sedangkan untuk kegiatan beternak lebih banyak dilakukan berimbang antara suami dan istri bahkan dilakukan secara bersama-sama. Dalam akses dan kontrol terhadap sumber daya ekonomi keluarga, suami lebih dominan dibanding istri, dan peran istri dalam pengambilan keputusan sangat kecil.
\end{abstract}

Kata kunci : Sistem pembagian kerja, akses, kontrol, sumber daya ekonomi, keluarga peternak sapi potong

\section{The Sistem of Work Difision, Access and Control toward the Source of Economic in the Family of Beef Cattle Farmer in Grobogan Regency}

\begin{abstract}
The research was aimed to analyze the system of work difision, access and control and to know the factors to be considered in deciding work defision, access and control toward the source of economic on the family of beef cattle farmer, based on the income from the effort of beef cattle farmer and the role to support productive economic of family, and to know gender happen in family of beef cattle farmer. The data collection was done in Grobogan Regency. The basis method of the research used was descriptive qualitative method, and the samples were taken with purposive sampling. Data were analyzed using interactive analysis (Interactive Model of analysis). The result of the result showed that husbands in the family of beef cattle farmer had more role on the work related with public (outdoor), and wives were only work on domestic sector as house wife (62\%), thus they did not get income (42\%). In the system of work difision to activity related with production, about 95\% were done by husband, and the production activity by wife (91\%). While for animal production, the activity was done together between husband and. For access and control toward source of economic family, husband more dominated than wife, and the role of wife to take decided was less than husband.
\end{abstract}

Key words : system of work division, access, source of economic, family of beef cattle farmer 


\section{PENDAHULUAN}

Peran wanita dalam pembangunan bangsa belum memperlihatkan hasil yang bisa diakui oleh semua pihak, hal ini dapat dilihat dari kesempatan bagi kaum wanita untuk mendapatkan pendidikan yang tinggi serta pekerjaan yang layak relatif masih tertinggal jika dibandingkan kaum pria. Sementara itu, peranan wanita seperti yang dicanangkan dalam (GBHN, 1999-2002) pada hakekatnya adalah upaya peningkatan kedudukan, peranan, kemampuan, kemandirian, dan ketahanan mental spiritual wanita sebagai bagian tak terpisahkan dari upaya peningkatan kualitas sumber daya manusia. Untuk itu pembinaan pernan wanita sebagai mitra sejajar pria dalam pembangunan harus dikembangkan dengan tetap memperhatikan kodrat serta harkat dan martabatnya.

Keluarga merupakan unit pengambilan keputusan terkecil dalam masyarakat. Kepala keluarga dituntut untuk lebih jika dibandingkan dengan istri, tetapi dalam kenyataan lain seorang istri sangat berperan dalam keluarga, bahkan memiliki peran ganda yaitu sebagai ibu rumah tangga, sekaligus bekerja membantu suami mencari nafkah. Perbedaan peran sosial antara laki-laki dengan perempuan seringkali dibenarkan dalam perbedaan biologis, sehingga melahirkan perbedaan peran dalam masyarakat. Perbedaan gender sebetulnya tidak menjadi masalah sepanjang tidak melahirkan ketidak adilan gender (gender inequalititas). Ketidakadilan gender adalah suatu sistem yang menempatkan perempuan dan laki-laki sebagai korban dari sistem tersebut (Fakih, 2001).

Manifesto dari ketidakadilan gender tersebut dapat dilihat dari bebagai bentuk, yaitu marginalisasi atau proses pemiskinan ekonomi, subordinasi atau anggapan tidak penting dalam suatu politik, pembentukan stereotif atau melalui pelabelan negatif, kekerasan, beban kerja lebih panjang dan lebih berat (burden), serta sosialisasi ideologi peran gender (Fakih, 2001). Idiologi gender yang dibangun atas dasar budaya untuk mengatur relasi manusia, telah mengkonstruksikan pembagian kerja atas dasar jenis kelamin, yang membuahkan hasil pembagian sifat, peran dan posisi atas dasar jenis kelamin pula (Muniarti et al, 2001).

Kemajuan zaman, tuntutan ekonomi keluarga serta kebutuhan akan tenaga kerja wanita telah mengubah pola pikir wanita Indonesia. Saat ini banyak wanita yang masuk ke dunia kerja dan terlibat dalam sektor publik, tetapi banyak juga wanita yang memilih pekerjaan domestik, hal ini dikarenakan mereka menyadari peran gender wanita dalam mendidik anak, mengurus keluarga, merawat serta mengelola rumah sehingga memilih pekerjaan yang bisa dikerjakan dirumah.

Salah satu pekerjaan yang bisa dikerjakan dirumah tetapi menghasilkan uang adalah beternak sapi potong rakyat. Didalam keluarga peternak rakyat, setiap anggota keluarga dituntut untuk bisa menyesuaikan dengan pendapatan atau dalam arti yang lain mereka dituntut hidup hemat dan membagi waktu. Dalam keluarga peternak, setiap anggota keluarga memiliki peran serta tugas masingmasing dimana pembagian kerja tersebut berdasarkan kesepakatan keluarga.

Penelitian ini bertujuan untuk menganalisis sistem pembagian kerja, akses dan kontrol terhadap sumber daya ekonomi dalam keluarga, mengetahui faktor-faktor yang menjadi pertimbangan dalam menentukan pembagian kerja, akses dan kontrol terhadap sumber daya ekonomi dalam keluarga, mengetahui besarnya pendapatan yang diterima dari usaha peternakan sapi potong serta peranannya dalam menunjang ekonomi produktif keluarga, serta mengetahui bias gender yang terjadi dalam keluarga peternak rakyat sapi potong.

\section{MATERI DAN METODE}

\section{Materi}

Penelitian ini dilaksanakan di Kabupaten Grobogan selama 8 bulan, dengan metode penentuan lokasi penelitian secara sengaja (purposive) (Singarimbun dan Effendi, 1995). Pemilihan Kabupaten Grobogan sebagai lokasi penelitian didasarkan pada pertimbangan, 
bahwa kabupaten ini menduduki peringkat ketiga di Propinsi Jawa Tengah dalam ketersediaan ternak sapi potong yaitu sebesar 118.630 ekor (Dinas Peternakan Propinsi Jawa Tengah, 2003), dan ternak sapi potong yang ada di kabupaten ini sebagian besar dikelola dalam bentuk peteranakan rakyat. Berdasarkan survai awal yang telah dilakukan, maka dapat ditentukan empat kecamatan yang ada di wilayah Kabupaten Grobogan sebagai lokasi penelitian, yaitu Kecamatan Kradenan, Gabus, Wirosari, dan Toroh. Pemilihan empat kecamatan ini sebagai lokasi penelitian dengan pertimbangan bahwa keempat kecamatan ini memiliki populasi ternak sapi tertinggi di Kabupaten Grobogan, yaitu Kecamatan Gabus 13.693 ekor, Kradenan 12.578 ekor, Wirosari 11.875 ekor, dan Toroh 11.744 ekor.

\section{Metode}

Penelitian ini merupakan bentuk penelitian deskriptif kualitatif yang mengkaji tentang bagaimana pembagian kerja berdasarkan akses dan kontrol terhadap sumber daya ekonomi dalam keluarga peternak rakyat sapi potong di Kabupaten Grobogan. Dalam penelitian ini digunakan sumber data berupa kata-kata dan tindakan subyektif serta data tertulis yang meliputi data primer dan sekunder. Data primer diperoleh dari wawancara atau interview secara langsung dari sumbernya, yaitu keluarga batih sedangkan data sekunder diperoleh melalui dokumen baik literatur, laporan-laporan, arsip serta data penelitian terdahulu. Data dikumpulkan dengan teknik observasi non partisipan, in-deph interview, dan melalui dokumentasi. Sampel dalam penelitian ini ditentukan dengan metode purposive sampling atau sampel bertujuan.

Analisa data penelitian menggunakan teknik analisa gender model bervard-1 atau HAF. Teknik Analisa data yang digunakan dalam penelitian ini adalah model analisis interaktif (Interactive Model of Analysis) yang memiliki 3 komponen yaitu reduksi data, penyajian data, dan penarikan kesimpulan. Dalam bentuk ini peneliti tetap bergerak diantara ketiga komponen dengan komponen pengumpul data selama proses pengumpulan data berlangsung. Sesudah pengumpulan data, kemudian bergerak diantara data reduksi, data display, dan conclusing drawing dengan menggunakan waktu yang tersisa bagi penelitiannya (Sutopo, 1998).

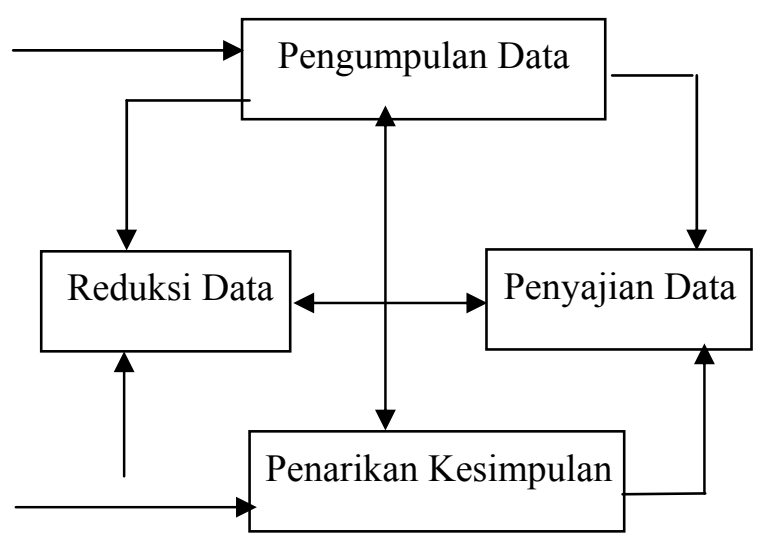

Gambar 1. Skema proses model analisis Miles dan Huberman 


\section{HASIL DAN PEMBAHASAN}

\section{Identitas Responden}

Upaya adopsi inovasi teknologi diperlukan oleh petani peternak dalam rangka perbaikan tingkat pendapatan. Ciri-ciri sosial dan ekonomi individu yang mempengaruhi tingkat adopsi inovasi antara lain umur, tingkat pendidikan, melek huruf, status sosial, tingkat pendapatan, luas lahan/besarnya usaha yang dimiliki, motivasi dan tujuan usaha (Roger, 1995). Dengan mengetahui karakteristik responden diharapkan dapat tergambarkan latar belakang peternak rakyat sapi potong di Kabupaten Grobogan.

\section{Jenis Kelamin}

Hasil penelitian menunjukkan bahwa mayoritas peternak sapi potong di Kabupaten Grobogan adalah laki-laki (94\%), sedangkan jumlah peternak wanita hanya $6 \%$ dari keseluruhan responden. Kondisi ini karena beternak merupakan pekerjaan yang lebih banyak melibatkan kegiatan fisik sehingga lebih cocok untuk laki-laki walaupun tidak menutup kemungkinan peternak adalah wanita.

\section{Umur}

Umur seseorang merupakan salah satu karakteristik individu yang besarannya mempengaruhi fungsi biologis dan psikologis individu tersebut. Hubungannya dengan kegiatan belajar umur seseorang dikaitkan dengan kapasitas dan efisiensi belajar mengajar serta kemampuan dalam menerima pengetahuan. Semakin muda umur seseorang biasanya mempunyai semangat ingin tahu yang makin besar terhadap hal-hal yang baru, sehingga ada kesan mereka lebih cepat atau responsif dalam menerima pengetahuan (Soekartawi, 2005).

Umur peternak sapi potong di lokasi penelitian berkisar antara 21-60 tahun, dengan distribusi umur merata pada golongan umur 3140 tahun yaitu sebesar $31 \%$ dari keseluruhan responden, serta golongan umur 41-50 tahun sebesar $30 \%$. Hasil penelitian juga menunjukkan bahwa lebih dari $90 \%$ peternak termasuk ke dalam usia produktif kerja, dimana menurut Shalahudin dan Kadir (1991) umur produktif tenaga kerja adalah pada rentang umur 15-55 tahun. Kondisi peternak yang mayoritas merupakan tenaga kerja produktif, diharapkan mampu mengembangkan budidaya ternak sapi potong di Kabupaten Grobogan.

\section{Pendidikan}

Azahari (1988) menyatakan bahwa tingkat pendidikan, baik formal maupun non formal adalah sarana untuk meningkatkan pengetahuan dan keterampilan. Seseorang yang mempunyai pendidikan dan pengetahuan teknis yang lebih banyak, akan lebih mudah dan lebih mampu berkomunikasi dengan baik. Karakteristik responden berdasarkan tingkat pendidikan disajikan pada Tabel 1 .

Hasil penelitian menunjukkan bahwa mayoritas responden berpendidikan formal SD, yaitu sebanyak 80 orang atau sebesar $80 \%$ dari jumlah responden. Rendahnya pendidikan peternak membatasi kemampuan dan ketrampilan mereka, sehingga ternak yang mereka budidayakan hanya dipelihara secara tradisional tanpa sentuhan teknologi, dimana kebanyakan dari mereka hanya memanfaatkan pakan yang tersedia di alam sekitar tanpa memberi makanan penunjang sehingga produktivitas ternak rendah. Kondisi ini sesuai dengan pendapat Soekartawi (2005) bahwa petani yang berpendidikan relative tinggi lebih cepat dalam melaksanakan adopsi inovasi, tetapi sebaliknya petani yang berpendidikan rendah agak sulit untuk mengadopsi teknologi dengan cepat.

\section{Pendapatan}

Tingkat pendapatan baik dari beternak sapi potong maupun pendapatan yang diperoleh selain dari beternak pada setiap keluarga bervariasi besarnya (Tabel 1). Pendapatan yang diterima responden dari beternak sapi potong, 
Tabel 1. Karakteristik Responden Berdasarkan Tingkat Pendapatan

\begin{tabular}{|c|c|c|c|c|c|c|}
\hline \multirow{2}{*}{ Pendapatan (Rp/bulan) } & \multicolumn{4}{|c|}{ Kode Kecamatan } & \multirow{2}{*}{ Jumlah } & \multirow{2}{*}{$\begin{array}{c}\text { Presentase } \\
(\%)\end{array}$} \\
\hline & I & II & III & IV & & \\
\hline \multicolumn{7}{|l|}{ Dari Beternak } \\
\hline$\leq 100.000$ & 15 & 1 & 2 & 16 & 34 & 34 \\
\hline $100.000-150.000$ & 6 & 11 & 11 & 2 & 30 & 30 \\
\hline $150.000-200.000$ & 3 & 5 & 7 & 5 & 20 & 20 \\
\hline $200.000-250.000$ & 1 & 1 & 2 & 2 & 6 & 6 \\
\hline$\geq 250.000$ & 0 & 7 & 3 & 0 & 10 & 10 \\
\hline Jumlah & 25 & 25 & 25 & 25 & 100 & 100 \\
\hline \multicolumn{7}{|l|}{ Selain Beternak } \\
\hline$\leq 250.000$ & 13 & 14 & 14 & 6 & 47 & 47 \\
\hline $250.000-500.000$ & 10 & 9 & 7 & 7 & 33 & 33 \\
\hline $500.000-750.000$ & 0 & 1 & 3 & 2 & 6 & 6 \\
\hline $750.000-1.000 .000$ & 2 & 1 & 1 & 2 & 6 & 6 \\
\hline$\geq 1.000 .000$ & 0 & 1 & 0 & 8 & 9 & 9 \\
\hline Jumlah & 25 & 25 & 25 & 25 & 100 & 100 \\
\hline
\end{tabular}

Keterangan Kode Kecamatan: I: Kradenan, II: Gabus, III: Wirosari, IV: Toroh.

Sumber : Data primer terolah, 2007.

hampir merata pada setiap tingkat pendapatan, namun demikian konsentrasi terbesar terdapat pada tingkat pendapatan $\leq \mathrm{Rp} .100 .000 /$ bulan sebanyak 34 orang atau $34 \%$ dari keseluruhan responden. Besar kecilnya pendapatan yang diterima dari kegiatan beternak sapi potong ini ditentukan oleh jumlah ternak yang dimiliki, semakin banyak jumlah ternak yang dimiliki maka pendapatan yang diterima setiap bulannya semakin tinggi dan sebaliknya.

Pendapatan yang diperoleh dari selain beternak menonjol pada kelompok tingkat pendapatan $\leq$ Rp. 250.000 yaitu sebanyak 47 orang atau $47 \%$ dari keseluruhan jumlah responden. Responden yang memiliki pendapatan diatas Rp. 1.000 .000 per bulan hanya 9 orang atau sebesar $9 \%$ dari jumlah responden. Rendahnya tingkat pendapatan responden dikarenakan mayoritas dari mereka hanya bekerja sebagai petani dengan penghasilan yang rendah, dikarenakan pertanian di Kabupaten Grobogan kurang produktif yang disebabkan oleh kondisi tanah dan iklim yang kurang mendukung dimana mayoritas sawah yang ada merupakan sawah tadah hujan. Oleh karena itu adanya pengembangan budidaya sapi potong di Kabupaten Grobogan diharapkan mampu meningkatkan pendapatan keluarga peternak, sehingga kesejahteraan mereka meningkat.

\section{Pekerjaan dan Pendapatan Istri}

Dalam keluarga, peran kepala keluarga dituntut untuk lebih jika dibandingkan dengan istri, tetapi dalam kenyataan lain seorang istri juga sangat berperan dalam keluarga, bahkan terkadang memiliki peran ganda yaitu sebagai ibu rumah tangga, sekaligus bekerja membantu suami mencari nafkah. Perbedaan peran sosial antara laki-laki dengan perempuan seringkali dibenarkan dalam perbedaan biologis.

Dari hasil penelitian dapat diketahui bahwa mayoritas responden (62\%) memiliki istri atau pasangan yang hanya bekerja pada sektor domestik saja yaitu sebagai ibu rumah tangga. Berdasarkan tingkat pendapatan yang diterima mayoritas istri tidak berpenghasilan yaitu sebanyak 42 orang atau $42 \%$, serta berpenghasilan rendah yaitu $<$ Rp. 250.000 per bulan sebanyak 33 orang atau sebesar 33\%. Banyaknya responden yang istrinya tidak memiliki penghasilan atau berpenghasilan rendah tersebut dikarenakan pada umumya mereka hanya bekerja pada sektor domestik sebagai ibu rumah tangga yang secara otomatis tidak berpenghasilan. Minimnya peran perempuan dalam kegiatan ekonomi produktif keluarga ini seringkali mengakibatkan terjadinya bias gender, serta lemahnya akses 
dan kontrol perempuan terhadap sumber daya ekonomi keluarga, walaupun peran perempuan dalam keluarga tidak hanya dilihat dari besar kecilnya sumbangan pendapatan dalam menunjang ekonomi produktif keluarga, tetapi masih banyak peran lain yang berpengaruh dalam keluarga.

\section{Pembagian Kerja dalam Keluarga Peternak Sapi Potong}

Pembagian kerja antara laki-laki dan perempuan dalam keluarga sering menjadi pangkal permasalahan dalam studi perempuan. Dalam penelitian ini pembagian kerja dibagi menjadi tiga kelompok, yaitu: 1) pekerjaan atau kegiatan produktif; 2) pekerjaan atau kegiatan reproduktif; 3) pekerjaan atau kegiatan politik dan sosial budaya. Pembagian kerja yang berkaitan dengan beternak dibatasi pada seluruh aktivitas yang berkaitan dengan tehnis pemeliharaan sapi potong, serta pendistribusiannya atau pembagian tugasnya oleh anggota keluarga. Aktivitas yang berhubungan dengan teknis pemeliharaan sapi potong terdiri dari membersihkan kandang dan lingkungan kandang, mengambil kotoran, memberikan pakan, mencari pakan, memandikan sapi dan menggembala sapi.

Untuk pekerjaan atau kegiatan produktif, yaitu kegiatan yang dilakukan anggota keluarga dalam rangka mencari nafkah, mayoritas dilakukan oleh suami, sedangkan pembagian kerja yang berkaitan dengan kegiatan reproduksi (mengerjakan pekerjaan rumah tangga, mengasuh anak) dalam keluarga mayoritas dilakukan oleh istri (Tabel 2). Kondisi ini sesuai dengan pendapat Nasikun (1990) cit. Wahyuningsih (1995) yang menyatakan Pola pembagian kerja dalam keluarga umumnya berdasarkan atas jenis kelamin, perempuan biasanya ditempatkan pada posisi yang harus menjalankan peran dan tanggungjawab yang berkaitan dengan pekerjaan domestik seperti mengasuh anak dan menyiapkan segala kepentingan keluarga, sedangkan laki-laki mendapat peran yang berkaitan dengan sektor publik atau berorientasi keluar rumah. Pembagian kerja yang menekankan laki-laki sebagai kepala keluarga dan pencari nafkah utama diterima dalam masyarakat. Berkaitan dengan kegiatan politik dan sosial budaya, banyak sekali aktivitas yang dilakukan oleh responden. Hal ini berkaitan dengan lokasi penelitian yang termasuk dalam masyarakat pedesaan, dimana masyarakat ini memiliki ciri kehidupan yang masih sederhana, tingkat kerukunan dan kepedulian yang tinggi, gotong royong, serta kepatuhan pada budaya dan adat istiadat yang masih kental. Aktivitas politik dan sosial budaya yang sering dijalani oleh responden antara lain kelompok tani/ternak, membantu tetangga pada saat mengadakan hajatan, kerja bakti, arisan, karang taruna, jamaah tahlil, pengajian, kegiatan kesenian, dan sebagainya.

Tabel 2. Pembagian Kerja Aktivitas/Kegiatan Produksi dan Reproduksi

\begin{tabular}{|c|c|c|c|c|c|c|}
\hline \multirow[t]{2}{*}{ Pembagian Kerja } & \multicolumn{4}{|c|}{ Kode Kecamatan } & \multirow[t]{2}{*}{ Jumlah } & \multirow{2}{*}{$\begin{array}{c}\text { Presentase } \\
(\%)\end{array}$} \\
\hline & I & II & III & IV & & \\
\hline \multicolumn{7}{|l|}{ Produksi } \\
\hline Suami & 24 & 25 & 25 & 21 & 95 & 95 \\
\hline Istri & 0 & 0 & 0 & 3 & 3 & 3 \\
\hline Anak Laki-laki & 1 & 0 & 0 & 1 & 2 & 2 \\
\hline Anak Perempuan & 0 & 0 & 0 & 0 & 0 & 0 \\
\hline Jumlah & 25 & 25 & 25 & 25 & 100 & 100 \\
\hline \multicolumn{7}{|l|}{ Reproduksi } \\
\hline Suami & 2 & 1 & 0 & 4 & 7 & 7 \\
\hline Istri & 23 & 23 & 25 & 20 & 91 & 91 \\
\hline Anak Laki-laki & 0 & 0 & 0 & 0 & 0 & 0 \\
\hline Anak Perempuan & 0 & 1 & 0 & 1 & 2 & 2 \\
\hline Jumlah & 25 & 25 & 25 & 25 & 100 & 100 \\
\hline
\end{tabular}

Sumber : Data primer terolah, 2007 
Tabel 3. Pembagian Kerja Aktivitas/Kegiatan Beternak Sapi Potong

\begin{tabular}{|c|c|c|c|c|c|c|}
\hline \multirow[t]{2}{*}{ Pembagian Kerja } & \multicolumn{4}{|c|}{ Kode Kecamatan } & \multirow[t]{2}{*}{ Jumlah } & \multirow{2}{*}{$\begin{array}{c}\text { Presentase } \\
(\%)\end{array}$} \\
\hline & I & II & III & IV & & \\
\hline \multicolumn{7}{|l|}{ Kegiatan A } \\
\hline Suami & 11 & 14 & 7 & 7 & 39 & 39 \\
\hline Istri & 8 & 4 & 3 & 9 & 24 & 24 \\
\hline Anak & 0 & 0 & 0 & 0 & 0 & 0 \\
\hline Semua & 6 & 7 & 15 & 9 & 37 & 37 \\
\hline Jumlah & 25 & 25 & 25 & 25 & 100 & 100 \\
\hline \multicolumn{7}{|l|}{ Kegiatan B } \\
\hline Suami & 10 & 11 & 7 & 5 & 33 & 33 \\
\hline Istri & 10 & 7 & 5 & 11 & 33 & 33 \\
\hline Anak & 1 & 0 & 0 & 0 & 1 & 1 \\
\hline Semua & 4 & 7 & 13 & 9 & 33 & 33 \\
\hline Jumlah & 25 & 25 & 25 & 25 & 100 & 100 \\
\hline \multicolumn{7}{|l|}{ Kegiatan C } \\
\hline Suami & 13 & 13 & 11 & 9 & 46 & 46 \\
\hline Istri & 8 & 4 & 3 & 7 & 22 & 22 \\
\hline Anak & 0 & 1 & 0 & 0 & 1 & 1 \\
\hline Semua & 4 & 7 & 11 & 9 & 31 & 31 \\
\hline Jumlah & 25 & 25 & 25 & 25 & 100 & 100 \\
\hline \multicolumn{7}{|l|}{ Kegiatan D } \\
\hline Suami & 10 & 14 & 9 & 6 & 39 & 39 \\
\hline Istri & 10 & 4 & 2 & 8 & 24 & 24 \\
\hline Anak & 0 & 0 & 0 & 0 & 0 & 0 \\
\hline Semua & 5 & 7 & 14 & 11 & 37 & 37 \\
\hline Jumlah & 25 & 25 & 25 & 25 & 100 & 100 \\
\hline \multicolumn{7}{|l|}{ Kegiatan E } \\
\hline Suami & 12 & 14 & 13 & 10 & 49 & 49 \\
\hline Istri & 6 & 2 & 0 & 5 & 13 & 13 \\
\hline Anak & 0 & 1 & 0 & 0 & 1 & 1 \\
\hline Semua & 7 & 8 & 12 & 10 & 37 & 37 \\
\hline Jumlah & 25 & 25 & 25 & 25 & 100 & 100 \\
\hline \multicolumn{7}{|l|}{ Kegiatan F } \\
\hline Suami & 14 & 15 & 12 & 7 & 48 & 48 \\
\hline Istri & 6 & 2 & 0 & 2 & 10 & 10 \\
\hline Anak & 0 & 1 & 0 & 0 & 1 & 1 \\
\hline Semua & 5 & 7 & 13 & 8 & 33 & 33 \\
\hline Tdk dilakukan & 0 & 0 & 0 & 8 & 8 & 8 \\
\hline Jumlah & 25 & 25 & 25 & 25 & 100 & 100 \\
\hline \multicolumn{7}{|l|}{ Kegiatan G } \\
\hline Suami & 7 & 6 & 0 & 2 & 15 & 15 \\
\hline Istri & 13 & 2 & 0 & 1 & 16 & 16 \\
\hline Anak & 0 & 0 & 0 & 0 & 0 & 0 \\
\hline Semua & 5 & 4 & 0 & 3 & 12 & 12 \\
\hline Tdk dilakukan & 0 & 13 & 25 & 19 & 57 & 57 \\
\hline Jumlah & 25 & 25 & 25 & 25 & 100 & 100 \\
\hline
\end{tabular}

Keterangan kegiatan: A: membersihkan kandang, B: membersihkan lingkungan sekitar kandang, C: mengambil kotoran, D: memberikan pakan, E: mencari pakan, Kegiatan F: memandikan sapi, G: menggembala sapi.

Sumber : Data primer terolah, 2007 
Berkaitan dengan kegiatan politik dan sosial budaya, banyak sekali aktivitas yang dilakukan oleh responden. Hal ini berkaitan dengan lokasi penelitian yang termasuk dalam masyarakat pedesaan, dimana masyarakat ini memiliki ciri kehidupan yang masih sederhana, tingkat kerukunan dan kepedulian yang tinggi, gotong royong, serta kepatuhan pada budaya dan adat istiadat yang masih kental. Aktivitas politik dan sosial budaya yang sering dijalani oleh responden antara lain kelompok tani/ternak, membantu tetangga pada saat mengadakan hajatan, kerja bakti, arisan, karang taruna, jamaah tahlil, pengajian, kegiatan kesenian, dan sebagainya.

Untuk pembagian kerja yang berkaitan dengan aktivitas beternak sapi potong dengan item pekerjaan seperti telah disebutkan diatas, secara rinci dapat dilihat pada Tabel 3 . Aktivitas yang berkaitan dengan pemeliharaan ternak sapi potong, cukup merata dalam pembagian kerjanya antara suami dan istri atau dilakukan secara bersama-sama oleh keduanya. Sedangkan peran anak dalam pembagian kerja beternak ini tidak terlalu tampak, hal ini lebih dikarenakan anak memiliki aktivitas lain yang lebih penting, misalnya sekolah atau belajar.

Akses dalam penelitian ini dibatasi pada kesempatan untuk memanfaatkan sumber daya keluarga tanpa adanya perasaan dan sikap saling menghalangi satu sama lain, sesuai kegiatan bersama yang disepakati. Sedangkan kontrol didefinisikan sebagai kewenangan penuh dalam mengambil keputusan dan penggunaan dan hasil pemanfaatan sumber daya keluarga. Dalam sebuah keluarga manakala perempuan hanya terlibat dalam kegiatan reproduksi maka akses ke sumber daya keluarga lebih banyak diminati oleh lakilaki. Hal ini juga terbukti dalam penelitian ini, dimana berdasarkan analisis data dapat diambil kesimpulan bahwa dalam akses serta kontrol terhadap sumber daya ekonomi keluarga yang lebih banyak berperan adalah kaum laki-laki atau suami (Tabel 4).

\section{Akses dan Kontrol Terhadap Sumber Daya Ekonomi}

Tabel 4 menunjukkan bahwa peran istri secara individual dalam akses dan kontrol terhadap sumber daya ekonomi keluarga sangat kecil. Dalam akses dan kontrol terhadap sumber daya ekonomi yang lebih dominan adalah suami, hal ini lebih dikarenakan yang lebih banyak berperan dalam memenuhi kebutuhan hidup keluarga, sehingga seolah-olah suamilah yang harus lebih banyak berperan dalam melakukan akses dan kontrol terhadap sumber daya ekonomi keluarga. Meskipun persentase responden yang menyatakan bahwa dalam melakukan akses dan kontrol terhadap sumber daya ekonomi keluarga dilakukan secara bersama-sama antara suami dan istri, namun disini peran istri juga sangat lemah yaitu hanya sebagai pendengar atau lebihnya sebagai pertimbangan, pengambil keputusan tetap suami.

Tabel 4. Akses dan Kontrol Terhadap Sumber Daya Ekonomi Keluarga

\begin{tabular}{|c|c|c|c|c|c|c|}
\hline \multirow{2}{*}{$\begin{array}{c}\text { Pengendali Akses dan } \\
\text { Kontrol } \\
\end{array}$} & \multicolumn{4}{|c|}{ Kode Kecamatan } & \multirow[t]{2}{*}{ Jumlah } & \multirow{2}{*}{$\begin{array}{c}\text { Presentase } \\
(\%)\end{array}$} \\
\hline & I & II & III & IV & & \\
\hline \multicolumn{7}{|l|}{ Akses } \\
\hline Suami & 9 & 4 & 2 & 14 & 29 & 29 \\
\hline Istri & 9 & 1 & 7 & 9 & 26 & 26 \\
\hline Suami\&Istri & 7 & 20 & 16 & 2 & 45 & 45 \\
\hline Jumlah & 25 & 25 & 25 & 25 & 100 & 100 \\
\hline \multicolumn{7}{|l|}{ Kontrol } \\
\hline Suami & 15 & 9 & 9 & 13 & 46 & 46 \\
\hline Istri & 0 & 0 & 0 & 12 & 12 & 12 \\
\hline Suami\&Istri & 10 & 16 & 16 & 0 & 42 & 42 \\
\hline Jumlah & 25 & 25 & 25 & 25 & 100 & 100 \\
\hline
\end{tabular}

Sumber : Data primer terolah, 2007 


\section{KESIMPULAN}

Dari hasil analisis terhadap data penelitian dapat disimpulkan bahwa dalam keluarga peternak sapi potong, suami lebih banyak berperan dalam pekerjaan yang berkaitan dengan publik (kegiatan diluar rumah), dan istri hanya bekerja pada sektor domestik yaitu sebagai ibu rumah tangga. Pada sistem pembagian kerja untuk aktivitas yang berkaitan dengan produksi mayoritas (95\%) dilakukan oleh suami, dan untuk aktivitas produksi lebih banyak dilakukan oleh istri (91\%). Sedangkan untuk kegiatan beternak lebih banyak dilakukan berimbang antara suami dan istri bahkan dilakukan secara bersama-sama. Dalam akses dan kontrol terhadap sumber daya ekonomi keluarga, suami lebih dominan dibanding istri, dan peran istri dalam pengambilan keputusan sangat kecil.

\section{DAFTAR PUSTAKA}

Fakih, M. 1999. Analisis Gender dan Transformasi sosial. Yogyakarta Pustaka Pelajar
Murniati A. Nunuk P., dkk. 2001. Gerakan Ekonomi Perempuan Sebagai basis Ekonomi Rakayat. Jakarta, Sebuah Refeleksi Pengalaman Lapangan, Benarena Panawara

Rogers, E.M. 1995. Diffusion of Innovation. 4th ed., The Free Press, New York

Saputro, E.P (ed)., 2001. Pemberdayaan Masyarakat Melalui Ketahanan PanganKajian Empiris LSM-LSM Mitra Yayasan Indonesia Sejahtera. Yayasan Indonesia Sejahtera. Jakarta.

Shalahuddin, M. dan A. Kadir. 1991. Ilmu Sosial Dasar. PT. Bina Ilmu, Surabaya

Singarimbun, M. dan S. Effendi. 1998. Metode Penelitian Survai. Penerbit LP3ES, Jakarta

Soekartawi. 2005. Prinsip Dasar Komunikasi Pertanian. Penerbit Universitas Indonesia Press, Jakarta

Sutopo, H.B. 1998. Metodologi Penelitian Kualitatif (dasar teori dan terapannya dalam penelitian humaniora). Sebelas Maret University Press, Surakarta

Wahyuningsih, S. 1995. Pola Kerja, Pengambilan Keputusan dan Penikmatan Hasil Kerja di Sektor Pertanian (Suatu Studi Analisis Gender). Pusat Studi Wanita, UNIBRAW. 